\title{
Application of Proteomic Technologies to Assess the Quality of Raw Pork and Pork Products: An Overview from Farm-To-Fork
}

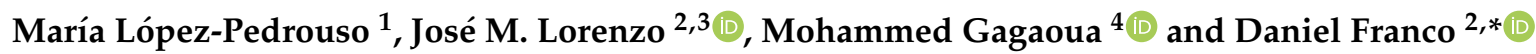 \\ 1 Department of Zoology, Genetics and Physical Anthropology, University of Santiago de Compostela, \\ 15872 Santiago de Compostela, Spain; mariadolores.lopez@usc.es \\ 2 Centro Tecnológico de la Carne de Galicia, Rúa Galicia N 4, Parque Tecnológico de Galicia, \\ 32900 San Cibrao das Viñas, Spain; jmlorenzo@ceteca.net \\ 3 Área de Tecnología de los Alimentos, Facultad de Ciencias de Ourense, Universidad de Vigo, \\ 32004 Ourense, Spain \\ 4 Food Quality and Sensory Science Department, Teagasc Ashtown Food Research Centre, Ashtown, \\ D15 DY05 Dublin 15, Ireland; gmber2001@yahoo.fr \\ * Correspondence: danielfranco@ceteca.net
}

Received: 4 October 2020; Accepted: 10 November 2020; Published: 11 November 2020

check for updates

Simple Summary: The swine industry has an important interest in becoming more efficient and innovative, fitting with the consumer demand in terms of pork quality, meat pig welfare conditions, and the environmental aspects. This paper deals with the productive (breed, diet, stress) and technological (aging, cooking) factors that affect fresh pork and elaborates the quality of products by using proteomic tools for assessing. These technologies are a relevant approach in the meat science field to decipher the underlying mechanisms and post-mortem changes in the muscle and biofluids proteome of pigs because their study will allow better management of the outcomes such as meat quality variation and defects. In general, these new developments in molecular techniques can help researchers to control and assess this quality through biomarkers. Additionally, as food safety and pork product authentication/adulteration to avoid fraud can be evaluated with these high-throughput proteomic tools, hence they were tackled. Finally, another relevant point addressed focused on the search of bioactive peptides with a beneficial effect on human health from added-value products such as dry-cured ham. Overall, this review describes the current and emerging proteomics studies dealing with raw pork and pork products from the farm to fork.

\begin{abstract}
The quality assurance of pork meat and products includes the study of factors prior to slaughter such as handling practices, diet and castration, and others during the post-mortem period such as aging, storage, and cooking. The development over the last two decades of high-throughput techniques such as proteomics offer great opportunities to examine the molecular mechanisms and study a priori the proteins in the living pigs and main post-mortem changes and post-translational modifications during the conversion of the muscle into the meat. When the most traditional crossbreeding and rearing strategies to improve pork quality were assessed, the main findings indicate that metabolic pathways early post-mortem were affected. Among the factors, it is well documented that pre-slaughter stress provokes substantial changes in the pork proteome that led to defective meat, and consequently, novel protein biomarkers should be identified and validated. Additionally, modifications in pork proteins had a strong effect on the sensory attributes due to the impact of processing, either physical or chemical. Maillard compounds and protein oxidation should be monitored in order to control proteolysis and volatile compounds. Beyond this, the search of bioactive peptides is becoming a paramount goal of the food and nutraceutical industry. In this regard, peptidomics is a major tool to identify and quantify these peptides with beneficial effects for human health.
\end{abstract}


Keywords: pig; high-throughput proteomic tools; meat quality; molecular biomarkers; traceability; authentication

\section{Introduction}

The global demand and industrial production of pork and pork products are increasing. According to the Food and Agriculture Organization of the United Nations (FAO) statistics, worldwide swine production has increased steadily from 1961 to 2007, with Asia the continent with the highest production with around 50\% of the total worldwide production. Between 2007 and 2017, production increased significantly in Asia and remained as the highest swine producers (almost $60 \%$ of the world total), since China assumed most of the production with more than 3700 million pigs produced during this time. Europe, with more than $25 \%$ of world production, is the second continent with the highest production. Germany, Poland, and Spain are the major countries with a remarkable rate in swine production [1]. Regarding pork consumption, the Asian continent is the area of the world with the greatest increase, from 2.8 million tons in 1961 to 67.4 in 2013, mainly related to China. For example, in 2013, pork demand in this country accounted for $80 \%$ of the Asian continent and around $50 \%$ worldwide [1].

From the above, it seems that the swine industry has significant interest in becoming more efficient and innovatively fitting with the consumer demand. Consumers are now demanding higher standards for the welfare of pigs and pork quality. Factors affecting the production system (breed, age/slaughter weight, sex, castration, and diet), pre-slaughter conditions (fasting, transport, lairage and stunning), and post-mortem interventions (electrical stimulation of the carcasses, aging, and storage conditions in terms of time/temperature, cooking, etc.) have an impact on pork eating quality, therefore, these factors should be carefully monitored during the whole continuum of farm-to-fork, especially at the industrial level. The relationship between animal welfare and pork quality has been detailed and rigorously researched from a proteomic point of view [2]. During the processing of meat, tenderness, color, and water holding capacity (WHC) traits are strongly impacted. Indeed, tenderness, intramuscular fat, cooking loss, and sensory traits are the main qualities of pork meat, which have been the most investigated and improved during the last decades. Currently, the meat research is focusing on a deeper understanding of the conversion of muscle into meat. This process results from myriad interconnected pathways including the enzymatic action of endogenous proteolytic enzymes of the muscle such as calpains; afterward, the impact of $\mathrm{pH}$ decline and that of lysosomal enzymes (cathepsins) that break the supramolecular structure of sarcomere as well as weakening the Z-discs, hence reducing the strength of the anchoring of the actomyosin complex and myofibrillar proteins [3]. In these stages, protein degradation plays an important role in the development of the pork quality traits ( $\mathrm{pH}$, color, WHC, and tenderness), causing when uncontrolled, serious technological defects and economic losses to occur [4].

One of the main problems associated with poor pork quality is the PSE (pale, soft, exudative) meat defect. This defect can be, for example, exacerbated by inadequate mixing with animals from different pens or batches raising fights and aggressions, increasing their stress pre-slaughter, hence causing PSE meat [5]. Stressed pigs are associated with a higher concentration of lactate and rapid $\mathrm{pH}$ decline during rigor mortis, provoking PSE meat [6]. Moreover, long journeys could result in lower carcass $\mathrm{pH}$ at $45 \mathrm{~min}$, leading to a high incidence of PSE meat [7]. Along the same line, an inadequate carcass cooling process could modify the metabolic processes and the extent of $\mathrm{pH}$ decline, hence leading to PSE meat [5]. In the case of PSE meat, changes in the sarcoplasmic and myofibrillar proteins are observed, and specifically, a lower solubility and higher denaturation of the proteins are evidenced [8]. This phenomenon could be the result of several biological pathways such as fast post-mortem glycolysis in the muscle, which are specifically targeted by activation of glycogen phosphorylase and phosphofructokinase, reducing the $\mathrm{pH}$ and protein denaturation and therefore 
inducing the PSE defect $[9,10]$. Consequently, pig stress has adverse consequences on fresh pork due to the impact on the transformation of muscle into meat. Considering the above, this is a major problem to the industry due to the economic losses, as this type of meat cannot be used for the elaboration of high-value cured meat products and other products. In this sense, a prediction of PSE through protein modifications would be a powerful strategy [11], among other emerging chemometric methods [10].

In the framework of high-throughput omics technologies, proteomics offers insights about the complex network of proteins and pathways underlying variation in pork quality. The study of the post-mortem muscle proteome together with protein-protein interactions, and post-translational modifications of proteins become a challenging task to deliver high-quality meat products [12]. In particular, the proteome is the result of a gene expression influenced by environmental and processing conditions related to the functional quality characteristics of the meat [13]. Gel-based proteomics and analytical approaches based on mass spectrometry are increasingly being used. In the proteomic workflow, often the initial step is a fraction of protein extracts separated using gel electrophoresis [one dimensional Sodium Dodecyl Sulfate Polyacrylamide Gel Electrophoresis (SDS-PAGE) or two-dimensional gel electrophoresis (2-DE)] coupled to liquid chromatography tools for identification. The large capacity and power of these technologies to study plant and animal products has been demonstrated [14-17]. Afterward, the bottom-up approach is the most common strategy resulting from the extraction of proteins and digestion by sequence-specific enzymes for later analysis by mass spectrometry [18]. It should be highlighted that those post-translational modifications of the proteins and their interactions with other proteins or macromolecules have a strong impact on pork tissues because of the change in the three-dimensional structure and consequently of the cellular functions [19]. Indeed, solubility, thermal stability, gelation, emulsifying, foaming, fat binging, and water-binding are only a few of parameters that directly depend on the protein structure, resulting in its great importance in food science [20]. For all these reasons, food proteomics, also known as foodomics [21], provide a great opportunity in the quality and safety controls of pork and pork products (Figure 1).

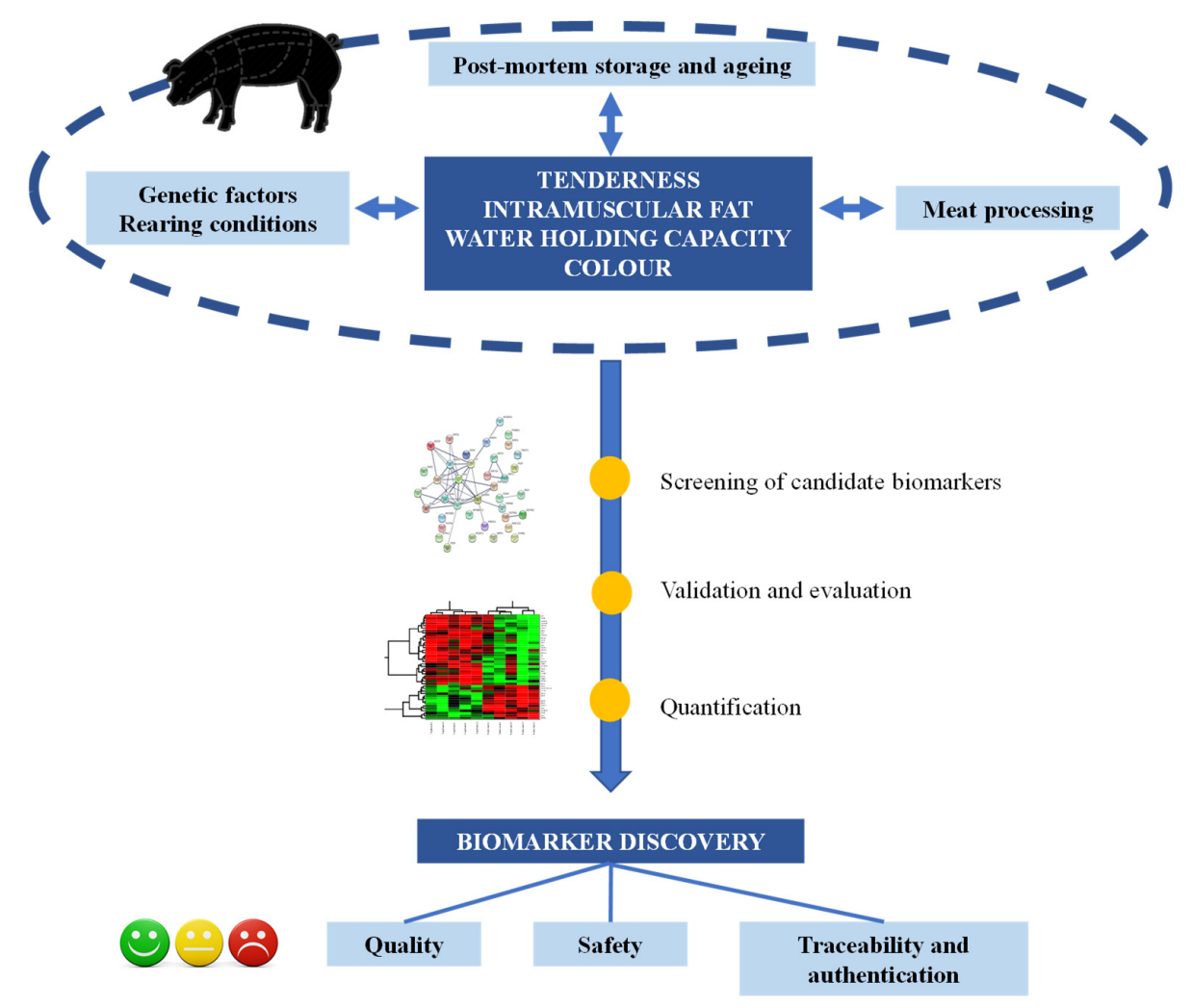

Figure 1. Proteomic workflow in the search for protein biomarkers regarding pork quality. 
Therefore, this review aimed to provide a summary of the current pork proteomics studies with the aim for a better understanding of the protein changes and their relationships with quality traits and the processing parameters of pork and its associated products. Thus, current technological advances and their integration with other traditional techniques are further briefly discussed. This review includes a current collection and non-exhaustive list of papers in the field, which have been discussed.

\section{Proteomic Perspective of Breeding and Rearing Practices}

For consumers, the perception of muscle color, texture, and marbling are the main aspects that drive their choice. The consumer's first impression is strongly associated with the pork color at the point of sale whereas muscle firmness/texture and marbling are used to predict the final eating quality. This complex network of sensory attributes defined by color, $\mathrm{pH}$, texture, water holding capacity, and marbling can be, for example, impacted by breed selection and rearing practices [22]. In general, meat quality traits are the result of genetic and environmental interactions. Therefore, livestock production systems including feeding, housing conditions, genotypes, behavioral, and physiological responses are widely recognized as the key factors driving pork quality. In recent years, different strategies aiming to improve the pork quality such as breed selection, animal management, and feeding, and other aspects of pork processing have been considered. Some recent studies in this context are briefly summarized in Table 1. Proteomics has mainly been employed to evaluate the meat quality by searching protein biomarkers and defining the molecular pathways as reviewed by Schilling et al. [4]. The great majority of proteomic experimental designs have been aimed to understand the underlying biological processes and identify biomarkers for meat processing [23].

\subsection{Influence of Pig Breed-Specific Differences among Genotypes for Final Pork Quality}

From a proteomic point of view, pig breed-specific differences among genotypes have shown different growth performances and fat accumulation as well as variations in the anaerobic activity of pig muscles after slaughter. These facts allow for explaining how differences in post-mortem temperature among breeds provoke differences in the activity of calpains and cathepsins, resulting in tender or tough meat [24]. Novel and traditional breeds are being developed to increase both productivity and pork quality. For instance, proteome analysis has proven that proteins associated with meat quality such as calcium ion binding proteins, Calsarcin 1, carbonic anhydrase 1 (CA1), myosin-binding protein $\mathrm{H}(\mathrm{MYBPH})$, and other metabolic proteins were differentially expressed between Tibetan (local) and Duroc $\times$ (Landrace $\times$ Yorkshire) (commercial) breeds. Meanwhile, the enrichment of Gene Ontology (GO) showed the purine-containing compound metabolic process as the molecular function, threonine-type peptidase activity as the molecular function, and mitochondrial inner membrane as the cellular component were the key aspects in the differentiation among these breeds [25]. Similarly, in another study that aimed to search for differences in the proteome of the Shaziling (local) versus Yorkshire breed, the GO term enrichment displayed the importance of metabolism, protein binding, and the regulation of skeletal muscle development within the differential proteins [26]. In both studies underlying the breed effect and differences in the proteome, the metabolic proteins were affected by genotype, indicating that the muscle fiber types were altered, and therefore, their metabolic properties. It has been demonstrated that metabolic properties influence the conversion of muscle to meat and meat quality in the early stages $[27,28]$, but post-mortem metabolic processes have a higher influence on tenderness, water holding capacity, and technological traits [29].

\subsection{Influence of Feed Efficiency on Pig Production}

Another relevant aspect of pig production is the residual feed intake (RFI) used to calculate the feed efficiency of growing animals at the farm. This trait may also be predicted using a proteomic approach as RFI can be correlated with molecular differences in skeletal muscle such as composition and muscle characteristics or other protein fluids such as plasma [30,31]. In this sense, low RFI is, for instance, associated with a greater proportion of fast-twitch glycolytic fibers characterized by higher 
glycolytic activity in comparison with high RFI [32]. Regarding metabolic pathways in skeletal muscle, proteomic studies have revealed that mitochondrial energy is lower for high feed efficiency. Moreover, the glucose-pyruvate-TCA-oxidative phosphorylation pathway has been identified as one of the key pathways of feed efficiency in pigs [31]. Vincent et al. [33] found similar results as the mitochondrial oxidative proteins had a lower abundance in pig muscles with lower RFI diet, reflecting a lower muscular oxidative stress. On the contrary, proteins involved in the glycolysis pathway had a higher abundance in pigs from a low-RFI ("efficient") compared with those from high-RFI pigs ("inefficient"). Another way to increase the feed and growth rate, carcass yield, and carcass leanness is to feed pigs with additives such as ractopamine. Under these conditions, the abundance of enzymes involved in glycolytic metabolism are also modified, producing alterations in the conversion of muscle to meat [34]. Even improving intramuscular fat by changing the pig diet provokes differential expression in the proteins belonging to pathways like energy metabolism, fiber type, and structure, specifically slow-twitch troponin 1 and myosin heavy chain IIb [35]. It may be inferred that different dietary conditions may lead to variations in muscle fiber type composition, and consequently, the different glycogen and lactate contents. As explained previously, changes in glycogen and lactate concentrations at the early post-mortem stage may impact meat quality and if excessive changes lead to defects in the final meat products [36].

\subsection{Influence of the Castration on Pork Quality}

On the other hand, within the swine industry, a widespread practice employed is the castration of male piglets. The main reasons why the pigs are castrated are an improvement in pig management, growth, carcass qualities, and mainly to avoid the unpleasant aroma and taste of pork perception related to "boar taint". This latter reason is probably the most important due to the odor and flavor characteristics in raw and cooked pork meat, which causes rejection. However, the controversy about the surgical castration of pigs has led to the search for alternatives such as immunocastration. This option consists of vaccinating against gonadotropin-releasing factor $(\mathrm{GnRH})$. However, there is little research about the effect of immunocastration on meat quality [37]. Using the LC-MS/MS approach, the proteomic differences among intact males and surgically (SC) and immunologically castrated (IC) pigs were revealed [38]. A total of 50 proteins were differentially abundant between the IC and SC treatments. Twenty-two proteins were greater in abundance for the IC group, while 27 with an abundance change fold higher than 1.5 varied between both castration methods studied. These findings suggest at first glance a strong relationship with pork quality development. In fact, the entire males showed an increase in oxidative metabolic profile than in the SC group. Furthermore, proteins involved in the cytoskeleton and immunity were abundant in the IC group, while several heat shock proteins and laminins were abundant in the SC group. In addition, the main structural proteins (actin and myosin heavy chain isoforms) were importantly degraded in the case of the entire animals in comparison to castrated pigs, although this was not a driver of more tender meat [39]. In a recent integromics study by Gagaoua and co-workers on cattle, the results on pork were consistent with the beef tenderness and color [14,17]. Briefly, the oxidative damage occurring in post-mortem muscle impacts the state of the structural proteins and increases the role of antioxidant and heat shock proteins that positively or negatively drive the final outcomes of these meat quality traits. Furthermore, in terms of the mechanisms, it seems that changes in the proteins of structure are related to other pathways such as oxidation, hence leading to the formation of protein aggregates that can negatively impact tenderness or color traits.

\subsection{Relationship between Pre-Slaughter Stress and Pork Quality}

The relationship between pre-slaughter stress and meat quality have been demonstrated, but several unknowns and more knowledge are needed at the molecular level, as reviewed by Mouzo et al. [2]. Apart from ethical considerations from consumers, pig stress largely creates PSE meat, causing economic losses, as indicated in the introduction. Pigs are particularly susceptible to heat stress 
because they lack sweat glands and skin insulation of subcutaneous fat. This major stressor provokes a metabolic and physiologic response. Additionally, certain pre-slaughter conditions such as mixing animals or long-term transportation increase the risk of the production of meat with high ultimate $\mathrm{pH}$ at the group level [40]. Studies looking at the relationship in detail showed that in pigs, levels of fighting were linearly related to increases in ultimate $\mathrm{pH}$ at the individual level [41]. At the molecular level, triosephosphate isomerase and transferrin have been proposed as biological markers for water holding capacity in the case of pigs under stress conditions [42]. In this regard, the hepatic proteome of pigs subjected to chronic heat stress was investigated, showing that proteins involved in response to stress (HSPs) and immune defense, response to oxidative stress, apoptosis, energy metabolism, signal transduction, and cytoskeleton were altered regardless of feeding. Overall, mechanisms of defense and homeostasis could be associated with heat stress, thereby contributing to the increase in meat shear force $[43,44]$. Specifically, the Halothane (HAL) genotype is characterized by suffering from a porcine stress syndrome, leading to the production of meat with poor quality such as PSE. The HAL mutation showed an upregulation of phosphorylation in proteins of calcium signaling, muscle contraction, glycogen, glucose and energy metabolism, and cellular stress, suggesting that among the proteins, $\mathrm{Ca}^{2+} /$ calmodulin-dependent protein kinase II was a key enzyme with an interplay role in these processes [45]. Additionally, post-translational modifications of metabolic enzymes were detected by 2-DE. These modifications can be used as specific patterns in response to short- and long-term heat stress [46]. More specifically, protein acetylation has been investigated in relation to heat stress for further knowledge of the conversion of muscle in meat $[47,48]$. Protein acetylation, together with phosphorylation, has been recognized to regulate the activity of enzymes and the stability of proteins amongst other functions. It has been reported that preslaughter stress produces a dynamic protein lysine acetylation/deacetylation, which is associated with muscle contraction, carbohydrate metabolism, apoptosis, and calcium signaling [49]. Furthermore, individual housing also causes animal stress and this stressor was used as a means to search for stress biomarkers, as demonstrated by Marco-Ramel et al. [50]. For the above reasons, it can be concluded that pig stress is a major issue that has a great influence on muscle proteome, and thus of meat quality, as seen through the presence of different isoforms and important post-translational modifications during the post-mortem period. 
Table 1. Recent studies regarding the effect of different production factors on improvements in pork quality.

\begin{tabular}{|c|c|c|c|c|c|}
\hline & Studied Factors & Protein Source & Proteomic Approach & Main Findings & Ref \\
\hline \multirow{3}{*}{ Genotypes } & $\begin{array}{l}\text { Genotypes: Tibetan and Duroc } \times \\
\text { (Landrace } \times \text { Yorkshire) (DLY). } \\
\text { Feasibility of using differential } \\
\text { proteomic analysis to discriminate } \\
\text { among pig breeds and cuts }\end{array}$ & Different muscle cuts & LC-MS/MS & $\begin{array}{l}\text { The differential proteins belong to two major categories: meat } \\
\text { quality-associated proteins (calcium ion binding protein, } \\
\text { Calsarcin 1, CA1 and MYBPH), and energy } \\
\text { metabolism-associated proteins (CSRP3, GSTK1, COX6A, } \\
\text { AMPD, and TXNL1). } \\
\text { Regardless of pork cuts, comparative proteome analysis } \\
\text { between Tibetan and DLY pork identified } 102 \text { differentially } \\
\text { abundant proteins. }\end{array}$ & [25] \\
\hline & $\begin{array}{l}\text { Genotypes: Chinese indigenous } \\
\text { Shaziling and the Yorkshire breeds }\end{array}$ & LD & 2-DE and MALDI-TOF/TOF & $\begin{array}{c}23 \text { differentially expressed proteins were identified and } \\
\text { associated with fatty acid metabolism, glycolytic pathway, } \\
\text { and skeletal muscle growth. These differentially expressed } \\
\text { genes and proteins are candidate genes for improving meat } \\
\text { quality in Shaziling pigs. }\end{array}$ & [26] \\
\hline & $\begin{array}{l}\text { Mechanisms of Halothane (HAL) and } \\
\text { Rendement Napole (RN) Genes }\end{array}$ & LD & $\begin{array}{l}\text { iTRAQ, } \mathrm{TiO}_{2} \text { enrichment } \\
\text { and LC-MS/MS }\end{array}$ & $\begin{array}{l}\text { The HAL mutation contributes to the upregulation of } \\
\text { phosphorylation in proteins related to calcium signaling, } \\
\text { muscle contraction, glycogen, glucose and energy } \\
\text { metabolism and cellular stress. }\end{array}$ & [45] \\
\hline \multirow{4}{*}{ Feeding } & $\begin{array}{l}\text { Feed efficiency: high-FE and low-FE } \\
\text { pigs were compared. }\end{array}$ & LD & $\begin{array}{l}\text { iTRAQ } \\
\text { LC-MS/MS }\end{array}$ & $\begin{array}{l}124 \text { proteins were differentially expressed between the high- } \\
\text { and low-FE pigs. The glucose-pyruvate-tricarboxylic } \\
\text { acid-oxidative phosphorylation energy metabolism signaling } \\
\text { pathway was an important regulated pathway. Enzymes } \\
\text { involved in the conversion of glucose to pyruvate were } \\
\text { upregulated in the high-FE pigs. }\end{array}$ & [31] \\
\hline & $\begin{array}{l}\text { Feed efficiency: Pigs with low-RFI } \\
\text { ("efficient") and high-RFI } \\
\text { ("inefficient") }\end{array}$ & LD & 2-DE and LC-MS/MS & $\begin{array}{l}11 \text { proteins showed a differential abundance between RFI } \\
\text { lines. However, the differentially expressed proteins were not } \\
\text { affected by feed restriction. }\end{array}$ & [33] \\
\hline & $\begin{array}{l}\text { Dietary ractopamine } \\
\text { supplementation to improve pork } \\
\text { leanness. }\end{array}$ & LD & 2-DE and MALDI-TOF/TOF & $\begin{array}{l}\text { Glyceraldehyde-3-phosphate dehydrogenase (GAPDH) and } \\
\text { phosphoglucomutase-1 (PGM1) were over-abundant in } \\
\text { control pigs, whereas serum albumin (ALB), carbonic } \\
\text { anhydrase } 3 \text { (CA3), L-lactate dehydrogenase A chain (LDHA), } \\
\text { fructose-bisphosphate aldolase A (ALDOA), and myosin } \\
\text { light chain 1/3 (MYL1) were over-abundant in pigs ingested } \\
\text { with ractopamine. Ractopamine suggested to influence the } \\
\text { abundance of enzymes involved in glycolysis. }\end{array}$ & [34] \\
\hline & $\begin{array}{l}\text { Dietary L-arginine supplementation } \\
\text { to reduce backfat thickness and } \\
\text { increase intramuscular fat (IMF). }\end{array}$ & LD & 2-DE and LC-MS/MS & $\begin{array}{l}\text { The proteome changes in LD muscle between the control and } \\
\text { supplemented pigs showed that L-arginine significantly } \\
\text { influenced the abundance of proteins involved in energy } \\
\text { metabolism, fiber type, and muscle structure. }\end{array}$ & [35] \\
\hline
\end{tabular}


Table 1. Cont.

\begin{tabular}{|c|c|c|c|c|c|}
\hline & Studied Factors & Protein Source & Proteomic Approach & Main Findings & Ref \\
\hline \multirow[t]{2}{*}{ Castration } & Immune and surgical castrated pigs & LD & $\begin{array}{l}\text { LC-MS/MS and Western } \\
\text { blot validation }\end{array}$ & $\begin{array}{l}\text { Fifty proteins were differentially abundant between the two } \\
\text { groups. Proteins involved in cytoskeleton and immunity } \\
\text { were more abundant in the immune castrated group. Several } \\
\text { heat shock proteins (HSPs) and laminins were abundant in } \\
\text { the surgical castrated group. }\end{array}$ & [38] \\
\hline & $\begin{array}{l}\text { Surgical castration against entire } \\
\text { male pigs }\end{array}$ & LD & 2-DE and MALDI-TOF/TOF & $\begin{array}{l}\text { Entire male pigs have a more oxidative metabolic profile than } \\
\text { surgically castrated pigs. More abundance of structural } \\
\text { protein fragments suggests a higher degree of proteolysis in } \\
\text { entire male pigs. }\end{array}$ & [39] \\
\hline Growth & $\begin{array}{l}\text { Muscle growth and lipid deposition. } \\
\text { Comparison between two Chinese } \\
\text { mini-type breeds and two western } \\
\text { breeds. }\end{array}$ & LD & $\begin{array}{l}\text { iTRAQ, } \\
\text { LC-MS/MS }\end{array}$ & $\begin{array}{l}288 \text { differentially abundant proteins of which } 169 \text { were } \\
\text { upregulated and } 119 \text { were downregulated between the two } \\
\text { types of genotypes. Among them, } 28 \text { were related to muscle } \\
\text { growth and } 15 \text { to lipid deposition. }\end{array}$ & [51] \\
\hline \multirow{5}{*}{ Animal welfare } & $\begin{array}{c}\text { Animal stress and welfare changes in } \\
\text { the housing system }\end{array}$ & Blood & $\begin{array}{l}\text { 2D-DIGE and } \\
\text { MALDI-TOF/TOF } \\
\text { iTRAQ }\end{array}$ & $\begin{array}{l}\text { Changes in two main homeostatic mechanisms: the innate } \\
\text { immune and redox systems. The acute phase proteins } \\
\text { haptoglobin, apolipoprotein A-I and } \alpha 1 \text {-antichymotrypsin } 3 \\
\text { (SERPINA3), and the antioxidant enzyme peroxiredoxin } 2 \\
\text { were differentially expressed. }\end{array}$ & {$[50]$} \\
\hline & $\begin{array}{l}\text { Heat stress. Effect of chronic heat } \\
\text { stress, thermal neutral and restricted } \\
\text { feed intake conditions on hepatic } \\
\text { proteomes }\end{array}$ & Liver & 2-DE and LC-MS/MS & $\begin{array}{l}\text { Forty-five hepatic proteins were differentially abundant } \\
\text { among groups. The proteins were involved in response to } \\
\text { stress and immune defense, oxidative stress response, cellular } \\
\text { apoptosis, energy metabolism, signal transduction, and } \\
\text { cytoskeleton. }\end{array}$ & [43] \\
\hline & $\begin{array}{l}\text { Heat stress. Effect of chronic heat } \\
\text { stress against thermal neutral on } \\
\text { meat quality }\end{array}$ & LD & 2-DE and LC-MS/MS & $\begin{array}{l}\text { Changes in the expression of myofibrillar proteins, glucose } \\
\text { and energy metabolism-related proteins, heat shock proteins, } \\
\text { and antioxidant enzymes might be affecting tenderness. }\end{array}$ & [44] \\
\hline & $\begin{array}{l}\text { Animal welfare (heat stress) Effect of } \\
\text { acute heat stress for } 2,4 \text { and } 6 \mathrm{~h} \\
\text { against thermal neutral on meat } \\
\text { quality }\end{array}$ & $\begin{array}{l}\text { ST (red and white } \\
\text { areas) }\end{array}$ & 2-DE and Western Blot & $\begin{array}{l}\text { Several proteins were altered affecting metabolism, cell } \\
\text { structure, chaperone, antioxidant, and proteolytic activity. } \\
\text { The proteome data showed that the muscle proteome was } \\
\text { altered from } 2 \mathrm{~h} \text { of heat stress. }\end{array}$ & [46] \\
\hline & Animal stress (lysine acetylation) & LD & $\begin{array}{l}\text { Acetylpeptide enrichment } \\
\text { and LC-MS/MS }\end{array}$ & $\begin{array}{l}\text { The acetylation of proteins was enriched in muscle } \\
\text { contraction, carbohydrate metabolism, cell apoptosis and } \\
\text { calcium signaling. }\end{array}$ & [49] \\
\hline
\end{tabular}

$\mathrm{LD}=$ Longissimus dorsi, $\mathrm{ST}=$ Semitendinosus. 


\section{Application of Proteomics to Assess Pork Quality and Authentication}

\subsection{Influence of Different Post-Mortem Traits on Pork Quality}

Meat quality is generally determined by farm production factors as well as by post-mortem interventions techniques applied at the industrial scale. Recent studies regarding the effect of different post-mortem traits aiming to assess and improve pork quality are shown in Table 2. Within pork quality, tenderness is the main important sensory quality trait that is mainly affected by connective tissue, intramuscular fat content, and myofibrillar structure, which may interact with storage time [52]. In the early stages of rigor mortis, meat tenderization is widely studied from a proteomic point of view. In this process, protein degradation due to the muscle enzymes, $\mathrm{pH}$ decline, and tissue oxidation are key factors in developing tenderness, flavor, color, and juiciness. In the case of protein oxidation, relevant biomarkers for the oxidative process are the group of peroxiredoxins that control the hydrogen peroxide concentration to protect cells. Indeed, peroxiredoxin-2 (PRDX2) was found to be more abundant in tenderer pork loin during the aging [53]. Furthermore, PRDX3 and PRDX6 were found to be significantly correlated with the lightness $\left(\mathrm{L}^{*}\right)$ and redness $\left(\mathrm{a}^{*}\right)$ color traits, respectively $[54,55]$. Other oxidative stress proteins were found to be related with pork color such as Parkinson disease protein 7 (PARK7), playing a pivotal role in cell protection against oxidative stress and cell death [55]. During the processing and storage of products, protein oxidation contributes to reduce pork quality [56]. For this reason, the storage technologies of pork were assessed to avoid protein oxidation. For instance, in the case of high-oxygen atmospheres, the disulfide bonds among myosins are formed as a result of cysteine and methionine oxidation. Additionally, the oxidation of both amino acids produces different oxidation products at different sites, representing a high complexity [57].

In the case of pork quality, proteomic technologies have been demonstrated to be very effective in the prediction of drip loss and ultimate $\mathrm{pH}$ from $50 \%$ to $80 \%$ of protein biomarkers in the total proteome [58]. This trend of prediction was further confirmed by Kwasiborski and co-workers on these quality traits as well others such as color parameters [55]. This means that proteomics is a promising approach to efficiently assess pork quality. An intense change of proteome was observed and associated with $\mathrm{pH}$, color, and drip loss traits, resulting in 140 differentially expressed proteins. Functional analysis showed a decreased release of $\mathrm{Ca}^{2+}$, lower contents of type II fibers and those of glycogen, which decreased the extent of glycogenolysis in high-quality meats from the longissimus dorsi muscle [21]. Considering only drip loss, an enrichment analysis resulted in sphingolipid metabolism and glycolysis/gluconeogenesis as key pathways significantly influencing drip loss [59]. However, water holding capacity trait over post-mortem aging is not yet fully understood by the preliminary proteomic studies and further work is needed [60]. On the other hand, intramuscular fat content positively influences the taste and is both regulated by adipogenesis and myogenesis, which balances the number and the size of adipocytes and myocytes [61]. A strategy to reduce the intramuscular fat is by lowering the use protein diets, which seems to be at the origin of the enhancement of glycolysis and the Krebs cycle pathways as well as modifications in mitochondria, contractile proteins, and calcium signaling, therefore, impacting the extent of the glycolytic to oxidative properties of fibers [62]. It is well-known that in pork quality, the fiber distribution of oxidative and glycolytic types (red and white muscles) is a key factor in post-mortem metabolism [63]. Myosin-1, myosin-4, troponin complex (fast), myosin light chains, and metabolic enzymes are overexpressed in glycolytic fibers and myosin-2, myosin-7, and myoglobin; meanwhile, mitochondrial oxidative metabolic enzymes were especially abundant in oxidative fibers [64]. The high amount of oxidative fibers suggests, at first glance, an increased quality due to the link with a higher amount of intramuscular fat.

\subsection{Proteomics and Authentication/Adulteration of Pork Products}

In addition to the above-mentioned, other objective of the pork industry is food authentication and the detection of adulterations. A non-extensive summary of pork product authentication/adulteration is shown in Table 2. The replacement of ingredients with undeclared species, animal tissues, 
and geographic origin or the distinction of non-ecological meat and freeze/thawed meat is a technical challenge for proteomics. This is a complex issue because proteins undergo chemical modifications such as Maillard reactions in highly processed food products, hampering efficient authentication. In animal species identification, a set of heat-stable peptide markers from myosin, myoglobin, hemoglobin, L-lactase dehydrogenase $A$, and $\beta$-enolase allows for the preliminary authentication of eleven types of white and red meats from chicken, duck, goose, turkey, pork, beef, lamb, rabbit, buffalo, deer, and horse [65]. Despite the fact that immunoassay techniques (ELISA) are often used to quantify target compounds, some disadvantages are likely to be the low efficiency and cross-reactivity between species, making more difficulties and hindering identifications. For example, the skeletal muscle protein troponin I detection was quantifiable from 8.7 to $52 \mathrm{ng} / \mathrm{mL}$ by the ELISA method, and similar results were achieved by 2-DE in combination with Matrix-Assisted Laser Desorption/Ionization-Time-Of-Flight (MALDI-TOF/TOF) [66]. In this regard, mass spectrometry becomes a relevant method to quantify specific peptides of different species that could be proposed as biomarkers. For example, five peptides from myosin were used to identify and quantify trace pork (up to $0.5 \%$ ) in meat mixtures by parallel reaction monitoring (PRM) [67]. On the other hand, pork products and unprocessed meat should be packed, distributed, and stored appropriately. Fresh meat is more appreciated than frozen meat because of the formation of ice crystals than can destroy the ultrastructure of the matrix and consequently denature the proteins, hence reducing the potential meat quality. By using meat exudates to search for protein biomarkers, it was possible to discriminate between fresh and frozen meat [68]. From this study, a total of 22 proteins were found as candidate discriminatory biomarkers using gel-based techniques. 
Table 2. Recent studies regarding the effect of different post-mortem traits aiming to assess and improve pork quality as well as studies related to food safety and pork product authentication/adulteration.

\begin{tabular}{|c|c|c|c|c|c|}
\hline & Studied Factors & Protein Source & Proteomic Approach & Main Findings & Ref \\
\hline \multirow{3}{*}{ Ageing } & $\begin{array}{l}\text { Ageing pork. Effect of protein } \\
\text { lysine acetylation in post-mortem } \\
\text { muscle changes }\end{array}$ & LD & $\begin{array}{l}\text { Acetilpeptide enrichment } \\
\text { and LC-MS/MS }\end{array}$ & $\begin{array}{l}\text { Acetylproteins involved in apoptosis, calcium signaling, } \\
\text { and IMP synthesis were identified in post-mortem porcine } \\
\text { muscle. The lysine acetylation of proteins regulate the } \\
\text { conversion of muscle into meat. }\end{array}$ & [47] \\
\hline & Tenderness and aging & LD & $\begin{array}{l}\text { 2D-DIGE and mass } \\
\text { spectrometry }\end{array}$ & $\begin{array}{l}\text { Soluble desmin and peroxiredoxin- } 2 \text { could be used as } \\
\text { biomarkers of tenderness in aged pork products. }\end{array}$ & [53] \\
\hline & $\begin{array}{c}\text { Protein oxidation (oxidation of } \\
\text { cysteine and methionine residues) } \\
\text { Effect of hydroxyl radicals on the } \\
\text { myosin }\end{array}$ & LD & $\begin{array}{l}\text { SDS-PAGE, cysteine and } \\
\text { methionine labelling and } \\
\text { LC-MS/MS }\end{array}$ & $\begin{array}{l}\text { The cysteine at the head of the myosin and that at the coiled } \\
\text { tail of myosin easily generated disulfide. Further, } \\
\text { the methionine at the coiled tail of myosin was more easily } \\
\text { oxidized than that of the head. }\end{array}$ & [57] \\
\hline \multirow{6}{*}{ Pork quality } & $\begin{array}{l}\text { Effect of proteome profiles on } \\
\text { meat quality (high-quality } \\
\text { samples against low-quality) }\end{array}$ & LD & $\begin{array}{l}\text { Tandem mass tag labelling } \\
\text { and mass spectrometry }\end{array}$ & $\begin{array}{l}\text { Lower degree of glycolysis in high-quality compared to } \\
\text { low-quality meat. The levels of oxidative stress and } \\
\text { apoptosis were low in high-quality meat. }\end{array}$ & [21] \\
\hline & $\begin{array}{l}\text { Meat quality: drip loss } \\
\text { Identification of candidate genes }\end{array}$ & LD & $\begin{array}{l}\text { Isotope coded protein } \\
\text { labelling followed by } \\
\text { selected reaction } \\
\text { monitoring analysis }\end{array}$ & $\begin{array}{l}\text { The enrichment analysis resulted in } 10 \text { pathways. The most } \\
\text { relevant pathways were sphingolipid metabolism and } \\
\text { glycolysis/gluconeogenesis in relation to drip loss. } \\
\text { It allowed proposing genetic markers and candidate genes } \\
\text { for drip loss. }\end{array}$ & [59] \\
\hline & $\begin{array}{l}\text { Meat quality: } \mathrm{pH} \text {, color traits, } \\
\text { drip loss, water holding capacity }\end{array}$ & LD & 2DE + MALDI-TOF & $\begin{array}{l}\text { Proteins associated with ultimate } \mathrm{pH} \text {, lightness, drip, } \\
\text { thawing and cooking loss were related to the glycolytic } \\
\text { pathway, phosphate transfer, or fiber type composition. } \\
\text { In the case of thawing loss, the proteins were related to } \\
\text { denaturation of myofibrils or lipid content. Redness } \\
\text { involved proteins were enriched in post-mortem oxidative } \\
\text { activity. }\end{array}$ & [55] \\
\hline & $\begin{array}{l}\text { Intramuscular variation, neat } \\
\text { quality (color, drip loss and } \\
\text { tenderness) and their relation to } \\
\text { proteome }\end{array}$ & LD & $\begin{array}{l}\text { Label-free quantification }+ \\
\text { LC-MS/MS }\end{array}$ & $\begin{array}{l}\text { Glycolysis enzymes (enolase 3, ALDOA, LDHA, PGM1, } \\
\text { and TPI1) were highly abundant in the medial and } \\
\text { posterior region. GAPDH and myoglobin were } \\
\text { overexpressed in the medial region }\end{array}$ & [69] \\
\hline & $\begin{array}{l}\text { Water holding capacity measured } \\
\text { as centrifugal exudate (High drip } \\
\text { vs. Low drip) across post-mortem } \\
\text { aging on different phenotypes }\end{array}$ & $\mathrm{LD}$ & $\begin{array}{l}\text { 2-D DIGE followed by } \\
\text { MALDI-TOF/TOF and } \\
\text { nano-ESI LC-MS/MS. }\end{array}$ & $\begin{array}{l}\text { Discriminatory proteins identified include metabolic } \\
\text { enzymes, stress response, transport and structural proteins. } \\
\text { Twenty-five proteins were used to discriminate between } \\
\text { high drips and lower drips with accuracy higher than } 72 \% \text {. }\end{array}$ & [60] \\
\hline & Intramuscular fat content & $\mathrm{LD}$ & $\begin{array}{l}\text { Tandem mass tag labelling } \\
\text { and parallel reaction } \\
\text { monitoring analysis }\end{array}$ & $\begin{array}{l}\text { ALDH1B1, OTX2, ANXA6 and Zfp512 were proposed as } \\
\text { candidate biomarkers associated with intramuscular fat } \\
\text { deposition and fat biosynthesis in Laiwu pigs. }\end{array}$ & [70] \\
\hline
\end{tabular}


Table 2. Cont

\begin{tabular}{|c|c|c|c|c|c|}
\hline & Studied Factors & Protein Source & Proteomic Approach & Main Findings & Ref \\
\hline & $\begin{array}{l}\text { Muscle fiber type distribution in } \\
\text { semimembranosus and } \\
\text { semitendinosus muscles }\end{array}$ & $\begin{array}{l}\text { SM, ST separated } \\
\text { into dark and light } \\
\text { portion }\end{array}$ & LC-MS/MS & $\begin{array}{l}\text { According to fiber type (oxidative vs. glycolytic) } \\
\text { distribution, differentially expressed muscle proteins was } \\
\text { detected resulting in intramuscular variations of pork } \\
\text { quality. }\end{array}$ & [64] \\
\hline & $\begin{array}{l}\text { Effect of feeding regime on } \\
\text { intramuscular fat increase. } \\
\text { Comparison between normal } \\
\text { protein diet vs. reduced protein } \\
\text { diet. }\end{array}$ & LD & iTRAQ and LC-MS/MS & $\begin{array}{l}\text { The categories "muscle contraction" and "structural } \\
\text { constituents of cytoskeleton" were the most significantly } \\
\text { up-regulated proteins in muscle from reduced protein diets } \\
\text { and up-regulated proteins involved in the regulation of } \\
\text { energy metabolism. }\end{array}$ & [62] \\
\hline \multirow{3}{*}{ Mislabeling } & $\begin{array}{l}\text { Authentication of pork in meat } \\
\text { mixtures (chicken, sheep and } \\
\text { beef) }\end{array}$ & Meat mixtures & $\begin{array}{l}\text { Parallel reaction } \\
\text { monitoring mass } \\
\text { spectrometry }\end{array}$ & $\begin{array}{l}\text { Five peptides from myosin were screened and then used for } \\
\text { pork detection by PRM of Orbitrap MS. The LOD in mixed } \\
\text { meat can be up to } 0.5 \% \text {. }\end{array}$ & [67] \\
\hline & $\begin{array}{l}\text { Adulteration. Search for } \\
\text { species-specific biomarker of } \\
\text { mammalian muscle tissues in raw } \\
\text { meat and meat products. }\end{array}$ & Meat mixtures & $\begin{array}{l}\text { 2-DE and } \\
\text { MALDI-TOF/TOF }\end{array}$ & $\begin{array}{l}\text { Troponin I (TnI) has been characterized as a potential } \\
\text { thermally stable and species-specific biomarker of } \\
\text { mammalian muscle tissues in raw meat (beef, pork, lamb, } \\
\text { and horse) and meat products. }\end{array}$ & [66] \\
\hline & $\begin{array}{l}\text { To discriminate fresh and } \\
\text { freeze-thawed pork }\end{array}$ & LD & $\begin{array}{c}\text { 2-DE and } \\
\text { MALDI-TOF/TOF }\end{array}$ & $\begin{array}{l}\text { Twenty-two proteins were discrimination markers for fresh } \\
\text { or and freeze-thawed pork. }\end{array}$ & [68] \\
\hline Food safety & $\begin{array}{l}\text { Prevention and control of } \\
\text { Salmonella typhimurium in pigs } \\
\text { along a time course of } 1,2 \text {, and } 6 \\
\text { days post infection }\end{array}$ & $\begin{array}{l}\text { Intestinal sections } \\
\text { (ileum and colon) }\end{array}$ & iTRAQ & $\begin{array}{l}\text { The expression changes in colon were found in proteins } \\
\text { involved in cell death and survival, tissue morphology or } \\
\text { molecular transport at the early stages and tissue } \\
\text { regeneration at } 6 \text { days post-infection. A higher number of } \\
\text { changes in protein expression was quantified in ileum at } \\
2 \text { days post-infection }\end{array}$ & [71] \\
\hline
\end{tabular}




\section{Advances in Proteomics for Pork Products}

Nowadays, pork is an important part of the diet of many cultures because of its great versatility and thee abundant foods that can be manufactured from sausage to a dry-cured ham. Indeed, in recent years, most pork meat is sold as ham, bacon, and sausages than fresh pork. Further processing of pork should be considered in great detail to achieve high quality and palatability of products. The quality is associated, as evidenced above, with protein structure and lipid and protein oxidative reactions occurring during industrial processing and storage. Therefore, proteomics emerges as a relevant field, giving rise to new knowledge and understanding of the mechanisms. Table 3 displays the recent studies regarding the use of proteomics/peptidomics to evaluate the quality of pork products.

\subsection{Technological Properties of Proteins}

Regarding the functional properties of proteins, sausages contain a major insoluble protein fraction with a high content of myofibrillar proteins compared to cooked hams. This insoluble protein fraction is rich in tropomyosin and myosin light chains forming aggregates with actin. Moreover, a high level of protein oxidation was identified due to oxidized methionine in cooked products. The myofibrillar network, together with coagulated sarcoplasmic protein matrices, establishes the gel properties of cooked pork products [72,73]. Salt is an essential ingredient for the elaboration of pork products, providing interesting flavors and tastes, and increasing their shelf life [74]. For this reason, a large part of pork products is marketed as cured products such as bacon and dry cured-ham. In the case of the latter product, low water activity $(<0.90)$ and the use of sodium chloride and nitrite allows for the production of a cured meat product with better stability. These conditions of the food matrix determine the protein hydrolysis, and consequently, the flavor and textural properties are very dependent on the intensity of proteolysis during the dry-cured ham ripening [75]. The major fraction of muscle proteins is the myofibril, responsible for muscle structure. It was demonstrated that proteolysis indices and adhesiveness were correlated to the degradation of myofibrillar proteins. Additionally, it was reported that $\alpha$-actin, myosin- 1 , and myosin- 4 could be used as protein biomarkers of proteolysis and adhesiveness [76].

Technical improvements were analyzed from a proteomic point of view, providing an insight into the molecular modifications occurring in the meat matrix. Regarding healthy pork products, reducing salt content without changing the sensory and textural properties is the main goal in the production of dry-cured ham. For instance, when a pressure treatment before salting was investigated, glycolytic enzymes as well as myofibrillar proteins were found differentially abundant in exudates, suggesting a faster loosening of the myofibrillar structure [77]. Other strategies to reduce salt content assayed in dry-cured ham are ultrasounds or high-pressure processing. High-pressure conditions caused proteolysis in dry-cured ham, releasing two important amino acids (leucine and isoleucine) in terms of their role in sensory traits in a significant concentration. This fact could be assessed measuring the secondary metabolites 2-methyl-butanal and 3-methyl-butanal, which are related to the proteolysis process [78]. Other emerging technologies were the use of ultrasounds on the sliced dry-cured ham to correct texture defects. We found that ultrasound thermal treatment strongly increased the degradation of proteins, specifically those of the myofibril [79]. Additionally, sarcoplasmic proteins showed an increased abundance due to ultrasound treatment, suggesting that they could be further used as biomarkers to control the impact of ultrasound process.

\subsection{Bioactive Peptides from Pork Products}

Beyond this technological aspect, the bioavailability and bioaccessibility of food proteins are key factors of meat products to assess their nutritional and healthiness potential [80]. These food peptides from the entire protein can reach the intestine as peptides or be liberated after digestion. These biopeptides have been demonstrated to have antidiabetic, cholesterol-lowering, antihypertensive, anticancer, antimicrobial, or antioxidant activity in different in vitro experiments $[81,82]$. However, 
it should also be considered that for the development of these new functional products, these small peptides and free amino acids influence the flavor and aroma of final products due to their bitterness [78]. In addition, their low bioavailability is the main problem that limits their utilization in functional foods. This fact is often associated with their selective intestinal uptake and physiological instability when peptides are taken orally, hence it is crucial to select adequate processing methods and less reactive matrices when producing biopeptides to maintain their structures and improve their bioaccessibility and bioavailability [82]. The amino acids and small peptides (di and tri-peptides) can be absorbed more easily during digestion, however, the food processing may produce Maillard compounds, oxidation of sulfur amino acids, and other side reactions that reduce the protein digestibility and quality. Additionally, the protein denaturation and subsequent aggregation contribute to a low bioavailability [83]. In this sense, peptidomics could be used as a tool for assessing the bioactivity of peptides and their relation to human health [84].

In the case of dry-cured ham, titin is an important protein responsible for muscle structure and is involved in the connection between actin and myosin. The degradation of this protein was assessed over the curing process, and titin-derived peptides (KDEAAKPKGPIKGVAKK, KKLRPGSGGEK, KNTDKWSECAR and ISIDEGKVL) have been proposed as candidate markers for processing time [85]. Moreover, the degradation of structural proteins (myosin, $\alpha$-actinin, and troponin- $\mathrm{T}$ ) and creatine kinase muscle type have been associated with the bitterness and adhesiveness of Jinhua ham. More in-depth, it has been demonstrated that cathepsin $\mathrm{B}$ and $\mathrm{B}+\mathrm{L}$ are primarily responsible for the bitterness and adhesiveness, together with excessive proteolysis [86]. As indicated above, protein oxidation is mainly behind the quality deterioration of cured products, as was demonstrated using a peptidomic approach. Effectively, most peptides of dry-cured hams were oxidized on the methionine site in their sequence. In this sense, peptides from the major myofibrillar proteins (nebulin, titin, myosin heavy chain, and troponin I) were the main oxidized entities [87].

The hydrolysis of food proteins and modifications are produced as a result of the cooking process. In the case of pork, a high cooking temperature leads to a reduction in digestibility with significantly different peptidomes. It seems that sites of trypsin cleavages remain more stable with temperature than pepsin cleavages [88]. This demonstrates that the cooking process has a great impact on protein digestibility. Moreover, the degree of salt in pork soup affected the protein modifications as confirmed by the fact that the proteolytic index was higher (5\%) in soup compared to the unsalted product $(2 \%)$. iTRAQ technology, which utilizes isobaric reagents to label the primary amines of peptides and proteins, revealed that 13 collagen proteins were differentially abundant in soup ( $2 \%$ salt) in comparison to soup without salt [89]. This means that the cooking times and temperature as well as other ingredients provoke changes in protein and peptide fraction and digestibility.

On the other hand, the search for bioactive peptides from vegetable and animal products is also carried out in cured pork products [90]. Bioactive peptides produced by gastrointestinal digestion or enzymatic hydrolysis and during food processing were evidenced [91]. In the case of curing, it was proved that peptides $(<1 \mathrm{kDa})$ from dry-cured Xuanwei showed more antioxidant activity than Jinhua ham. A high scavenging effect against $\mathrm{O}^{2-}$ was measured by the 2,2-diphenyl-1-picrylhydrazyl (DPPH) method by the hydrolyzation of myosin, troponin, and actin [92]. 
Table 3. Recent studies regarding the use of proteomics/peptidomics to evaluate the quality of pork products.

\begin{tabular}{|c|c|c|c|c|}
\hline Product & Objective & Proteomic Technology & Main Findings & Ref \\
\hline $\begin{array}{l}\text { Cooked pork products (cooked } \\
\text { ham and emulsion sausages) }\end{array}$ & $\begin{array}{l}\text { Effect of cooking process on } \\
\text { protein modifications }\end{array}$ & $\begin{array}{l}\text { 2-DE and } \\
\text { MALDI-TOF/TOF }\end{array}$ & $\begin{array}{l}\text { The protein aggregation systems of cooked hams and emulsion } \\
\text { sausages reflect the heat processing conditions. The disulfide } \\
\text { bridges and additional covalent interprotein links determine the } \\
\text { final product. }\end{array}$ & {$[72,73]$} \\
\hline Parma dry-cured ham & $\begin{array}{l}\text { Effect of pressure treatment } \\
\text { before salting stage }\end{array}$ & $\begin{array}{l}\text { 2D-PAGE and } \\
\text { LC-ESI-MS/MS }\end{array}$ & $\begin{array}{l}\text { Specific proteins were found differentially abundant in exudates } \\
\text { from pressed versus unpressed hams. The pressure caused a } \\
\text { faster loosening of the myofibrillar structure with the release of } \\
\text { specific groups of proteins }\end{array}$ & [77] \\
\hline Dry-Cured Ham & $\begin{array}{l}\text { Effect of Proteolysis indices and } \\
\text { adhesiveness on proteins } \\
\quad \text { degradation } \\
\text { Use of high pressure and } \\
\text { ultrasound to correct textural } \\
\text { defect in dry-cured ham }\end{array}$ & $\begin{array}{l}\text { 2-DE and } \\
\text { MALDI-TOF/TOF }\end{array}$ & $\begin{array}{c}\text { Myosin-1, } \alpha \text {-actin and myosin- } 4 \text { proteins were the main changing } \\
\text { due to proteolysis. } \\
\text { The high-pressure conditions caused a greater level of proteolysis } \\
\text { displaying that actin was differentially degraded, unlike myosin. } \\
\text { Fragments of the major myofibrillar protein were abundantly } \\
\text { caused by ultrasound heating. }\end{array}$ & {$[76,78,79]$} \\
\hline Dry-cured ham (Jinhua) & $\begin{array}{l}\text { Sensory attributes (formation } \\
\text { mechanisms of bitterness and } \\
\text { adhesiveness) in raw, normal } \\
\text { and defective hams }\end{array}$ & LC-MS/MS & $\begin{array}{l}\text { Defective hams showed more proteolytic index that normal ham. } \\
\text { Creatine kinase, myosin, } \alpha \text {-actinin and troponin-T showed the } \\
\text { most intense response to bitterness and adhesiveness of } \\
\text { dry-cured ham. Myosin was proposed as a suitable biomarker to } \\
\text { monitor bitterness and adhesiveness }\end{array}$ & [86] \\
\hline Dry-cured ham & $\begin{array}{l}\text { Peptide oxidation in PDO } \\
\text { Teruel dry-cured ham }\end{array}$ & nESI-LC-MS/MS & $\begin{array}{l}\text { KDEAAKPKGPIKGVAKK, KKLRPGSGGEK, KNTDKWSECAR } \\
\text { and ISIDEGKVL were proposed as peptide biomarkers of } \\
\text { processing conditions. }\end{array}$ & [87] \\
\hline Cooked pork & $\begin{array}{l}\text { Effect of cooking on peptidomic } \\
\text { profile and digestibility }\end{array}$ & $\begin{array}{l}\text { SDS-PAGE and } \\
\text { MALDI-TOF/TOF }\end{array}$ & $\begin{array}{l}\text { The cooking process led to a reduction in digestibility. Peptides } \\
\text { sequenced from pepsin-digested samples under lower degrees of } \\
\text { doneness disappeared as the temperature increased. The trypsin } \\
\text { cleavages appeared more consistent among different degrees of } \\
\text { cooking }\end{array}$ & [88] \\
\hline Pork soup & $\begin{array}{c}\text { Protein modifications in } \\
\text { presence of salt (treated } 2 \% \text { ) and } \\
\text { without salt (control) }\end{array}$ & i-TRAQ & $\begin{array}{l}\text { Proteolytic index of salted samples was } 5 \% \text { higher than the } \\
\text { control and } 112 \text { differentially abundant proteins were detected. }\end{array}$ & [89] \\
\hline Dry-cured ham & $\begin{array}{l}\text { Antioxidant peptides from } \\
\text { Xuanwei (XHP) and Jinhua } \\
\text { (JHP) ham }\end{array}$ & $\begin{array}{l}\text { nano-LC-MS/MS and } \\
\text { quadrupole ion trap } \\
\text { Orbitrap spectrometer }\end{array}$ & $\begin{array}{l}\text { XHP showed higher antioxidant ability than JHP. } \\
\text { The oligopeptides with less than } 1000 \mathrm{Da} \text { and high antioxidant } \\
\text { activity were detected. }\end{array}$ & [92] \\
\hline Dry-Cured Ham & $\begin{array}{c}\text { Degradation of sarcoplasmic } \\
\text { proteins }\end{array}$ & $\begin{array}{l}\text { nLC-MS/MS and } \\
\text { SDS-PAGE }\end{array}$ & $\begin{array}{l}\text { Twenty proteins were identified and quantified suggesting } \\
\text { intense degradation during processing. }\end{array}$ & [93] \\
\hline
\end{tabular}




\section{Conclusions and Future Prospects}

Proteomics is an emerging technology for the rapid and sensitive identification of biomarkers aiming to assess the potential quality of pork products and the impact of food processing technologies. Genetic and rearing conditions influencing technological and sensory meat quality provoke different biochemical and molecular reactions that are regulated by several proteins and pathways including metabolic enzymes. Furthermore, pork quality determined by tenderness, color, drip loss, and intramuscular fat is conducted by structural and sarcoplasmic proteins. In this regard, proteins play a key role in the textural and sensory quality of pork fresh, showing the importance of the study of muscle proteome in pork. The most relevant quality traits were assessed by gel and mass spectrometry analysis. Gel-based proteomics are widely used for the search of protein biomarkers of these quality traits. Even the most sensitive gel-based methods such as protein labeling with fluorescent dyes as fluorescence difference gel electrophoresis (DIGE) were considered. However, gel-free alternatives such as Sequential Window Acquisition of All Theoretical Mass Spectra (SWATH-MS), Liquid chromatography-mass spectrometry/mass spectrometry (LC-MS/MS), or Isobaric tags for relative and absolute quantitation (iTRAQ) should be employed to enhance the efficiency of our quest for protein biomarkers and further validate previous results. Other technical improvements in pork processing were assessed from a proteomic perspective, providing an insight into protein modifications. Peptidomic profiles could further offer an overall overview of the protein digestibility and bioavailability that determine the effect of protein fraction on human health. In the framework of data analysis, we expect that statistics will play a great role in future proteomics, especially in handling the huge data produced by different proteomics methods. Regarding this, we expect that there is great interest in combining different omics techniques in the framework of multi-omics to study the interplay between different macromolecules in relation to the pork phenome. Indeed, phenomics or high-throughput phenotyping is becoming a reality in livestock production systems including pork, and we expect that this global approach will play an important role in the next years and decades.

Author Contributions: Conceptualization, M.L.-P., J.M.L., M.G. and D.F.; Writing-original draft preparation, M.L.-P. and D.F.; Writing-review and editing, M.L.-P., J.M.L., M.G. and D.F. All authors have read and agreed to the published version of the manuscript.

Funding: José M. Lorenzo and Daniel Franco are members of the HealthyMeat network, funded by CYTED (Programa Iberoamericano de Ciencia y Tecnología para el Desarrollo) (ref. 119RT0568). Our thanks go to GAIN (Axencia Galega de Innovación, Xunta de Galicia, Spain) for supporting this research (grant number IN607A2019/01). Mohammed Gagaoua is grateful to the funding received from Marie Skłodowska-Curie, grant agreement no. 713654 .

Conflicts of Interest: The authors declare no conflict of interest.

\section{References}

1. FAOSTAT. Available online: http://www.fao.org/faostat/en/\#data/QL (accessed on 1 September 2020).

2. Mouzo, D.; Rodríguez-vázquez, R.; Lorenzo, J.M.; Franco, D.; Zapata, C.; López-Pedrouso, M. Proteomic application in predicting food quality relating to animal welfare. A review. Trends Food Sci. Technol. 2020, 99, 520-530. [CrossRef]

3. Bee, G.; Anderson, A.L.; Lonergan, S.M.; Huff-Lonergan, E. Rate and extent of $\mathrm{pH}$ decline affect proteolysis of cytoskeletal proteins and water-holding capacity in pork. Meat Sci. 2007, 76, 359-365. [CrossRef] [PubMed]

4. Schilling, M.W.; Suman, S.P.; Zhang, X.; Nair, M.N.; Desai, M.A.; Cai, K.; Ciaramella, M.A.; Allen, P.J. Proteomic approach to characterize biochemistry of meat quality defects. Meat Sci. 2017, 132, 131-138. [CrossRef] [PubMed]

5. Sionek, B.; Przybylski, W. The Impact of Ante- and Post-Mortem Factors on the Incidence of Pork Defective Meat - A Review. Ann. Anim. Sci. 2016, 16, 333-345. [CrossRef]

6. Zhang, X.; Owens, C.M.; Schilling, M.W. Meat: The edible flesh from mammals only or does it include poultry, fish, and seafood? Anim. Front. 2017, 7, 12-18. [CrossRef]

7. Faucitano, L.; Goumon, S. Transport of Pigs to Slaughter and Associated Handling; Elsevier: Oxford, UK, 2018; ISBN 9780081011195. 
8. Warner, R.D.; Kauffman, R.G.; Greaser, M.L. Muscle protein changes post mortem in relation to pork quality traits. Meat Sci. 1997, 45, 339-352. [CrossRef]

9. López-Pedrouso, M.; Franco, D.; Serrano, M.P.; Maggiolino, A.; Landete-Castillejos, T.; De Palo, P.; Lorenzo, J.M. A proteomic-based approach for the search of biomarkers in Iberian wild deer (Cervus elaphus) as indicators of meat quality. J. Proteom. 2019, 205, 103422. [CrossRef]

10. Théron, L.; Sayd, T.; Chambon, C.; Vautier, A.; Ferreira, C.; Aubry, L.; Ferraro, V.; Santé-Lhoutellier, V. Toward the prediction of PSE-like muscle defect in hams: Using chemometrics for the spectral fingerprinting of plasma. Food Control 2020, 109, 106929. [CrossRef]

11. Xu, Z.; Shao, Y.; Liu, G.; Xing, S.; Zhang, L.; Zhu, M.; Xu, Y.; Wang, Z. Proteomics analysis as an approach to understand the formation of pale, soft, and exudative (PSE) pork. Meat Sci. 2020, 138049. [CrossRef]

12. Munekata, P.E.S.; Pateiro, M.; López-Pedrouso, M.; Gagaoua, M.; Lorenzo, J.M. Foodomics in meat quality. Curr. Opin. Food Sci. 2020, 163947. [CrossRef]

13. Hollung, K.; Veiseth, E.; Jia, X.; Færgestad, E.M.; Hildrum, K.I. Application of proteomics to understand the molecular mechanisms behind meat quality. Meat Sci. 2007, 77, 97-104. [CrossRef] [PubMed]

14. Gagaoua, M.; Terlouw, E.M.C.; Mullen, A.M.; Franco, D.; Warner, R.D.; Lorenzo, J.M.; Purslow, P.P.; Gerrard, D.; Hopkins, D.L.; Troy, D.; et al. Molecular signatures of beef tenderness: Underlying mechanisms based on integromics of protein biomarkers from multi-platform proteomics studies. Meat Sci. 2020, 172, 108311. [CrossRef] [PubMed]

15. López-Pedrouso, M.; Bernal, J.; Franco, D.; Zapata, C. Evaluating two-dimensional electrophoresis profiles of the protein phaseolin as markers of genetic differentiation and seed protein quality in common bean (Phaseolus vulgaris L.). J. Agric. Food Chem. 2014, 62, 7200-7208. [CrossRef]

16. Mato, A.; Rodríguez-Vázquez, R.; López-Pedrouso, M.; Bravo, S.; Franco, D.; Zapata, C. The first evidence of global meat phosphoproteome changes in response to pre-slaughter stress. BMC Genom. 2019, 20, 1-15. [CrossRef] [PubMed]

17. Gagaoua, M.; Hughes, J.; Terlouw, E.M.C.; Warner, R.D.; Purslow, P.P.; Lorenzo, J.M.; Picard, B. Proteomic biomarkers of beef colour. Trends Food Sci. Technol. 2020, 101, 234-252. [CrossRef]

18. Andjelković, U.; Josić, D. Mass spectrometry based proteomics as foodomics tool in research and assurance of food quality and safety. Trends Food Sci. Technol. 2018, 77, 100-119. [CrossRef]

19. Mittal, S.; Saluja, D. Modifications: Role in Protein Structure, Function and Stability; Springer: New Delhi, India, 2015; pp. 25-37, ISBN 9788132224679.

20. Foegeding, E.A.; Davis, J.P. Food protein functionality: A comprehensive approach. Food Hydrocoll. 2011, 25, 1853-1864. [CrossRef]

21. Hou, X.; Liu, Q.; Meng, Q.; Wang, L.; Yan, H.; Zhang, L.; Wang, L. TMT-based quantitative proteomic analysis of porcine muscle associated with postmortem meat quality. Food Chem. 2020, 328, 127133. [CrossRef]

22. Bonneau, M.; Lebret, B. Production systems and influence on eating quality of pork. Meat Sci. 2010, 84, 293-300. [CrossRef]

23. Picard, B.; Lefèvre, F.; Lebret, B. Meat and fish flesh quality improvement with proteomic applications. Anim. Front. 2012, 2, 18-25. [CrossRef]

24. D'Alessandro, A.; Marrocco, C.; Zolla, V.; D'Andrea, M.; Zolla, L. Meat quality of the longissimus lumborum muscle of Casertana and Large White pigs: Metabolomics and proteomics intertwined. J. Proteom. 2011, 75, 610-627. [CrossRef] [PubMed]

25. Mi, S.; Li, X.; Zhang, C.H.; Liu, J.Q.; Huang, D.Q. Characterization and discrimination of Tibetan and Duroc $\times$ (Landrace $\times$ Yorkshire) pork using label-free quantitative proteomics analysis. Food Res. Int. 2019, 119, 426-435. [CrossRef] [PubMed]

26. Yang, H.; Xu, X.; Ma, H.; Jiang, J. Integrative analysis of transcriptomics and proteomics of skeletal muscles of the Chinese indigenous Shaziling pig compared with the Yorkshire breed. BMC Genet. 2016, 1-13. [CrossRef] [PubMed]

27. Picard, B.; Gagaoua, M.; Gagaoua, M. Muscle Fiber Properties in Cattle and Their Relationships with Meat Qualities: An Overview. J. Agric. Food Chem. 2020, 68, 6021-6039. [CrossRef] [PubMed]

28. Lee, S.H.; Joo, S.T.; Ryu, Y.C. Skeletal muscle fiber type and myofibrillar proteins in relation to meat quality. Meat Sci. 2010, 86, 166-170. [CrossRef]

29. Lametsch, R.; Bendixen, E. Proteome analysis applied to meat science: Characterizing post mortem changes in porcine muscle. J. Agric. Food Chem. 2001, 49, 4531-4537. [CrossRef] 
30. Wang, X.; Wu, W.; Lin, G.; Li, D.; Wu, G.; Wang, J. Temporal Proteomic Analysis Reveals Continuous Impairment of Intestinal Development in Neonatal Piglets with Intrauterine Growth Restriction research articles. J. Proteome Res. 2010, 9, 924-935. [CrossRef]

31. Fu, L.; Xu, Y.; Hou, Y.; Qi, X.; Zhou, L.; Liu, H.; Luan, Y.; Jing, L.; Miao, Y.; Zhao, S.; et al. Proteomic analysis indicates that mitochondrial energy metabolism in skeletal muscle tissue is negatively correlated with feed efficiency in pigs. Sci. Rep. 2017, 7, 1-8. [CrossRef]

32. Faure, J.; Lefaucheur, L.; Bonhomme, N.; Ecolan, P.; Meteau, K.; Coustard, S.M.; Kouba, M.; Gilbert, H.; Lebret, B. Consequences of divergent selection for residual feed intake in pigs on muscle energy metabolism and meat quality. Meat Sci. 2013, 93, 37-45. [CrossRef]

33. Vincent, A.; Louveau, I.; Gondret, F.; Tréfeu, C.; Gilbert, H.; Lefaucheur, L. Divergent selection for residual feed intake affects the transcriptomic and proteomic profiles of pig skeletal muscle. J. Anim. Sci. 2015, 93, 2745-2758. [CrossRef]

34. Costa-Lima, B.R.C.; Suman, S.P.; Li, S.; Beach, C.M.; Silva, T.J.P.; Silveira, E.T.F.; Bohrer, B.M.; Boler, D.D. Dietary ractopamine influences sarcoplasmic proteome profile of pork Longissimus thoracis. Meat Sci. 2015, 103, 7-12. [CrossRef] [PubMed]

35. Ma, X.; Zheng, C.; Hu, Y.; Wang, L.; Yang, X.; Jiang, Z. Dietary L-arginine supplementation affects the skeletal longissimus muscle proteome in finishing pigs. PLoS ONE 2015, 10, e0117294. [CrossRef] [PubMed]

36. Choe, J.H.; Choi, Y.M.; Lee, S.H.; Shin, H.G.; Ryu, Y.C.; Hong, K.C.; Kim, B.C. The relation between glycogen, lactate content and muscle fiber type composition, and their influence on postmortem glycolytic rate and pork quality. Meat Sci. 2008, 80, 355-362. [CrossRef] [PubMed]

37. Grela, E.R.; Kowalczuk-vasilev, E.; Florek, M.; Kosior-korzecka, U.; Ska, P. An attempt of implementation of immunocastration in swine production-Impact on meat physicochemical quality and boar taint compound concentration in the meat of two native pig breeds. Livest. Sci. 2020, 232. [CrossRef]

38. Shi, X.; Li, C.; Cao, M.; Xu, X.; Zhou, G.; Xiong, Y.L. Comparative proteomic analysis of longissimus dorsi muscle in immuno- and surgically castrated male pigs. Food Chem. 2016, 199, 885-892. [CrossRef]

39. Škrlep, M.; Tomažin, U.; Lukač, N.B.; Poklukar, K.; Čandek-Potokar, M. Proteomic profiles of the longissimus muscles of entire male and castrated pigs as related to meat quality. Animals 2019, 9, 74. [CrossRef]

40. Terlouw, E.M.C.; Arnould, C.; Auperin, B.; Berri, C.; Le Bihan-duval, E.; Deiss, V. Pre-slaughter conditions, animal stress and welfare: current status and possible future research. Animal 2008. [CrossRef]

41. Terlouw, C. Stress reactions at slaughter and meat quality in pigs: genetic background and prior experience A brief review of recent findings. Livest. Prod. Sci. 2005, 94, 125-135. [CrossRef]

42. Di Luca, A.; Elia, G.; Hamill, R.; Mullen, A.M. 2D DIGE proteomic analysis of early post mortem muscle exudate highlights the importance of the stress response for improved water-holding capacity of fresh pork meat. Proteomics 2013, 13, 1528-1544. [CrossRef]

43. Cui, Y.; Hao, Y.; Li, J.; Bao, W.; Li, G.; Gao, Y.; Gu, X. Chronic Heat Stress Induces Immune Response, Oxidative Stress Response, and Apoptosis of Finishing Pig Liver: A Proteomic Approach. Int. J. Mol. Sci. 2016, 17, 393. [CrossRef]

44. Cui, Y.; Hao, Y.; Li, J.; Gao, Y.; Gu, X. Proteomic changes of the porcine skeletal muscle in response to chronic heat stress. J. Sci. Food Agric. 2018, 98, 3315-3323. [CrossRef] [PubMed]

45. Huang, H.; Scheffler, T.L.; Gerrard, D.E.; Larsen, M.R.; Lametsch, R. Quantitative Proteomics and Phosphoproteomics Analysis Revealed Different Regulatory Mechanisms of Halothane and Rendement Napole Genes in Porcine Muscle Metabolism. J. Proteome Res. 2018, 17, 2834-2849. [CrossRef] [PubMed]

46. Cruzen, S.M.; Baumgard, L.H.; Gabler, N.K.; Pearce, S.C.; Lonergan, S.M. Temporal proteomic response to acute heat stress in the porcine muscle sarcoplasm. J. Anim. Sci. 2017, 95, 3961. [CrossRef] [PubMed]

47. Jiang, S.; Liu, Y.; Shen, Z.; Zhou, B.; Shen, Q.W. Acetylome profiling reveals extensive involvement of lysine acetylation in the conversion of muscle to meat. J. Proteom. 2019, 205, 103412. [CrossRef]

48. Zou, B.; Zhao, D.; He, G.; Nian, Y.; Yan, J.; Li, C. Acetylation and Phosphorylation of Proteins A ff ect Energy Metabolism and Pork Quality. J. Agric. Food Chem. 2020. [CrossRef]

49. Zhou, B.; Shen, Z.; Liu, Y.; Wang, C.; Shen, Q.W. Proteomic analysis reveals that lysine acetylation mediates the effect of antemortem stress on postmortem meat quality development. Food Chem. 2019, 293, 396-407. [CrossRef] 
50. Marco-ramell, A.; Arroyo, L.; Peña, R.; Pato, R.; Saco, Y.; Fraile, L.; Bendixen, E.; Bassols, A. Biochemical and proteomic analyses of the physiological response induced by individual housing in gilts provide new potential stress markers. BMC Vet. Res. 2016, 12, 265. [CrossRef]

51. Wang, Z.; Shang, P.; Li, Q.; Wang, L.; Chamba, Y.; Zhang, B.; Zhang, H.; Wu, C. ITRAQ-based proteomic analysis reveals key proteins affecting muscle growth and lipid deposition in pigs. Sci. Rep. 2017, 7, 1-11. [CrossRef]

52. Van Laack, R.L.J.M.; Stevens, S.G.; Stalder, K.J. The influence of ultimate $\mathrm{pH}$ and intramuscular fat content on pork tenderness and tenderization. J. Anim. Sci. 2001, 79, 392-397. [CrossRef]

53. Carlson, K.B.; Prusa, K.J.; Fedler, C.A.; Steadham, E.M.; Huff-Lonergan, E.; Lonergan, S.M. Proteomic features linked to tenderness of aged pork loins. J. Anim. Sci. 2017, 95, 2533-2546. [CrossRef]

54. Hwang, I.H.; Park, B.Y.; Kim, J.H.; Cho, S.H.; Lee, J.M. Assessment of postmortem proteolysis by gel-based proteome analysis and its relationship to meat quality traits in pig longissimus. Meat Sci. 2005, 69, 79-91. [CrossRef]

55. Kwasiborski, A.; Sayd, T.; Chambon, C.; Santé-lhoutellier, V.; Rocha, D.; Terlouw, C. Pig Longissimus lumborum proteome: Part II: Relationships between protein content and meat quality. Meat Sci. 2008, 80, 982-996. [CrossRef] [PubMed]

56. Traore, S.; Aubry, L.; Gatellier, P.; Przybylski, W.; Jaworska, D.; Kajak-siemaszko, K.; Santé-lhoutellier, V. Higher drip loss is associated with protein oxidation. Meat Sci. 2012, 90, 917-924. [CrossRef] [PubMed]

57. Lu, H.; Luo, Y.; Lametsch, R. Proteomic profiling of oxidized cysteine and methionine residues by hydroxyl radicals in myosin of pork. Food Chem. 2018, 243, 277-284. [CrossRef] [PubMed]

58. Te Pas, M.F.W.; Kruijt, L.; Pierzchala, M.; Crump, R.E.; Boeren, S.; Keuning, E.; Hoving-Bolink, R.; Hortós, M.; Gispert, M.; Arnau, J.; et al. Identification of proteomic biomarkers in M. Longissimus dorsi as potential predictors of pork quality. Meat Sci. 2013, 95, 679-687. [CrossRef] [PubMed]

59. Welzenbach, J.; Neuhoff, C.; Heidt, H.; Cinar, M.U.; Looft, C.; Schellander, K.; Tholen, E.; Große-Brinkhaus, C. Integrative analysis of metabolomic, proteomic and genomic data to reveal functional pathways and candidate genes for drip loss in pigs. Int. J. Mol. Sci. 2016, 17, 1426. [CrossRef] [PubMed]

60. Di Luca, A.; Hamill, R.M.; Mullen, A.M.; Slavov, N.; Elia, G. Comparative Proteomic Profiling of Divergent Phenotypes for Water Holding Capacity across the Post Mortem Ageing Period in Porcine Muscle Exudate. PLoS ONE 2016, 11, e0150605. [CrossRef]

61. Ceciliani, F.; Lecchi, C.; Bazile, J.; Bonnet, M. Proteomics research in the adipose tissue. Proteom. Domest. Anim. Farm Syst. Biol. 2018, 233-254. [CrossRef]

62. Pires, V.M.R.; Madeira, M.S.; Dowle, A.A.; Thomas, J.; Almeida, A.M.; Prates, J.A.M. Increased intramuscular fat induced by reduced dietary protein in finishing pigs: Effects on the longissimus lumborum muscle proteome. Mol. Biosyst. 2016, 12, 2447-2457. [CrossRef]

63. Lefaucheur, L. A second look into fibre typing - Relation to meat quality. Meat Sci. 2010, 84, $257-270$. [CrossRef]

64. Kim, G.D.; Yang, H.S.; Jeong, J.Y. Intramuscular variations of proteome and muscle fiber type distribution in semimembranosus and semitendinosus muscles associated with pork quality. Food Chem. 2018, 244, 143-152. [CrossRef] [PubMed]

65. Stachniuk, A.; Sumara, A.; Montowska, M.; Fornal, E. Liquid chromatography-mass spectrometry bottom-up proteomic methods in animal species analysis of processed meat for food authentication and the detection of adulterations. Mass Spectrom. Rev. 2019. [CrossRef] [PubMed]

66. Zvereva, E.A.; Kovalev, L.I.; Ivanov, A.V.; Kovaleva, M.A.; Zherdev, A.V.; Shishkin, S.S.; Lisitsyn, A.B.; Chernukha, I.M.; Dzantiev, B.B. Enzyme immunoassay and proteomic characterization of troponin I as a marker of mammalian muscle compounds in raw meat and some meat products. Meat Sci. 2015, 105, 46-52. [CrossRef] [PubMed]

67. Pan, X.D.; Chen, J.; Chen, Q.; Huang, B.F.; Han, J.L. Authentication of pork in meat mixtures using PRM mass spectrometry of myosin peptides. RSC Adv. 2018, 8, 11157-11162. [CrossRef]

68. Kim, G.; Jeong, T.; Yang, H.; Joo, S.; Jin, S.; Jeong, J. Proteomic analysis of meat exudates to discriminate fresh and freeze-thawed porcine longissimus thoracis muscle. LWT Food Sci. Technol. 2015, 62, 1235-1238. [CrossRef]

69. Kim, G.; Jeong, J.; Yang, H.; Jin, S. Differential abundance of proteome associated with intramuscular variation of meat quality in porcine longissimus thoracis et lumborum muscle. Meat Sci. 2019, 149, 85-95. [CrossRef] 
70. Ma, C.; Wang, W.; Wang, Y.; Sun, Y.; Kang, L.; Zhang, Q.; Jiang, Y. TMT-labeled quantitative proteomic analyses on the longissimus dorsi to identify the proteins underlying intramuscular fat content in pigs. J. Proteom. 2020, 213, 103630. [CrossRef]

71. Collado-Romero, M.; Aguilar, C.; Arce, C.; Lucena, C.; Codrea, M.C.; Morera, L.; Bendixen, E.; Moreno, Á.; Garrido, J.J. Quantitative proteomics and bioinformatic analysis provide new insight into the dynamic response of porcine intestine to Salmonella Typhimurium. Front. Cell. Infect. Microbiol. 2015, 5. [CrossRef]

72. Di Luccia, A.; la Gatta, B.; Rutigliano, M.; Rusco, G.; Gagliardi, R.; Picariello, G. Protein Modifications in Cooked Pork Products; Elsevier Inc.: Amsterdam, The Netherlands, 2017; ISBN 9780128040577.

73. Di Luccia, A.; la Gatta, B.; Nicastro, A.; Petrella, G.; Lamacchia, C.; Picariello, G. Protein modifications in cooked pork products investigated by a proteomic approach. Food Chem. 2015, 172, 447-455. [CrossRef]

74. Vidal, V.A.S.; Lorenzo, J.M.; Munekata, P.E.S.; Pollonio, M.A.R. Challenges to reduce or replace $\mathrm{NaCl}$ by chloride salts in meat products made from whole pieces-a review. Crit. Rev. Food Sci. Nutr. 2020, 1-13. [CrossRef] [PubMed]

75. Domínguez, R.; Purriños, L.; Pérez-Santaescolástica, C.; Pateiro, M.; Barba, F.J.; Tomasevic, I.; Campagnol, P.C.B.; Lorenzo, J.M. Characterization of Volatile Compounds of Dry-Cured Meat Products Using HS-SPME-GC/MS Technique. Food Anal. Methods 2019, 12, 1263-1284. [CrossRef]

76. López-Pedrouso, M.; Pérez-Santaescolástica, C.; Franco, D.; Fulladosa, E.; Carballo, J.; Zapata, C.; Lorenzo, J.M. Comparative proteomic profiling of myofibrillar proteins in dry-cured ham with different proteolysis indices and adhesiveness. Food Chem. 2018, 244, 238-245. [CrossRef] [PubMed]

77. Paredi, G.; Benoni, R.; Pighini, G.; Ronda, L.; Dowle, A.; Ashford, D.; Thomas, J.; Saccani, G.; Virgili, R.; Mozzarelli, A. Proteomics of Parma Dry-Cured Ham: Analysis of Salting Exudates. J. Agric. Food Chem. 2017, 65, 6307-6316. [CrossRef] [PubMed]

78. López-Pedrouso, M.; Pérez-Santaescolástica, C.; Franco, D.; Carballo, J.; Zapata, C.; Lorenzo, J.M. Molecular insight into taste and aroma of sliced dry-cured ham induced by protein degradation undergone high-pressure conditions. Food Res. Int. 2019, 122, 635-642. [CrossRef]

79. López-Pedrouso, M.; Pérez-Santaescolástica, C.; Franco, D.; Carballo, J.; Garcia-Perez, J.V.; Benedito, J.; Zapata, C.; Lorenzo, J.M. Proteomic footprint of ultrasound intensification on sliced dry-cured ham subjected to mild thermal conditions. J. Proteom. 2019, 193, 123-130. [CrossRef]

80. Sun, X.; Acquah, C.; Aluko, R.E.; Udenigwe, C.C. Considering food matrix and gastrointestinal effects in enhancing bioactive peptide absorption and bioavailability. J. Funct. Foods 2020, 64, 103680. [CrossRef]

81. López-Pedrouso, M.; Borrajo, P.; Pateiro, M.; Lorenzo, J.M.; Franco, D. Antioxidant activity and peptidomic analysis of porcine liver hydrolysates using alcalase, bromelain, flavourzyme and papain enzymes. Food Res. Int. 2020, 137. [CrossRef]

82. Udenigwe, C.C.; Fogliano, V. Food matrix interaction and bioavailability of bioactive peptides: Two faces of the same coin? J. Funct. Foods 2017, 35, 9-12. [CrossRef]

83. López-Pedrouso, M.; Lorenzo, J.M.; Zapata, C.; Franco, D. Proteins and amino acids. In Innovative Thermal and Non-Thermal Processing; Barba, F.J., Saraiba, J.M.A., Cravotto, G., Lorenzo, J.M., Eds.; Elsevier Inc.: Duxford, UK, 2019; pp. 139-168, ISBN 9781469816593.

84. Dupont, D. Peptidomic as a tool for assessing protein digestion. Curr. Opin. Food Sci. 2017, 16, 53-58. [CrossRef]

85. Gallego, M.; Mora, L.; Aristoy, M.C.; Toldrá, F. Titin-derived peptides as processing time markers in dry-cured ham. Food Chem. 2015, 167, 326-339. [CrossRef]

86. Zhou, C.Y.; Wang, C.; Tang, C.B.; Dai, C.; Bai, Y.; Yu, X.B.; Li, C.B.; Xu, X.L.; Zhou, G.H.; Cao, J.X. Label-free proteomics reveals the mechanism of bitterness and adhesiveness in Jinhua ham. Food Chem. 2019, 297, 125012. [CrossRef] [PubMed]

87. Gallego, M.; Mora, L.; Aristoy, M.C.; Toldrá, F. Evidence of peptide oxidation from major myofibrillar proteins in dry-cured ham. Food Chem. 2015, 187, 230-235. [CrossRef] [PubMed]

88. Wen, S.; Zhou, G.; Li, L.; Xu, X.; Yu, X.; Bai, Y.; Li, C. Effect of cooking on in vitro digestion of pork proteins: A peptidomic perspective. J. Agric. Food Chem. 2015, 63, 250-261. [CrossRef] [PubMed]

89. Zhu, C.; Zhao, G.; Cui, W.; Li, S.; Yu, X.; Zhang, Q. Utilization of i-TRAQ technology to determine protein modifications in pork soup in response to addition of salt. J. Food Compos. Anal. 2020, 88, 103453. [CrossRef] 
90. Lorenzo, J.M.; Munekata, P.E.S.; Gómez, B.; Barba, F.J.; Mora, L.; Pérez-Santaescolástica, C.; Toldrá, F. Bioactive peptides as natural antioxidants in food products-A review. Trends Food Sci. Technol. 2018, 79, 136-147. [CrossRef]

91. Daliri, E.B.-M.; Oh, D.H.; Lee, B.H. Bioactive peptides. Foods 2017, 6, 32. [CrossRef]

92. Xing, L.; Liu, R.; Gao, X.; Zheng, J.; Wang, C.; Zhou, G.; Zhang, W. The proteomics homology of antioxidant peptides extracted from dry-cured Xuanwei and Jinhua ham. Food Chem. 2018, 266, 420-426. [CrossRef]

93. Gallego, M.; Mora, L.; Aristoy, M.C.; Toldrá, F. The use of label-free mass spectrometry for relative quantification of sarcoplasmic proteins during the processing of dry-cured ham. Food Chem. 2016, 196, 437-444. [CrossRef]

Publisher's Note: MDPI stays neutral with regard to jurisdictional claims in published maps and institutional affiliations.

(C) 2020 by the authors. Licensee MDPI, Basel, Switzerland. This article is an open access article distributed under the terms and conditions of the Creative Commons Attribution (CC BY) license (http://creativecommons.org/licenses/by/4.0/). 